\title{
AQUISIÇÃO E INTERPRETAÇÃO DE ANOMALIAS GRAVIMÉTRICAS DO QUADRILÁTERO FERRÍFERO, SE DO CRÁTON SÃO FRANCISCO
}

\author{
Luiz Gustavo Rodrigues Pinto ${ }^{1}$, Naomi Ussami² e Nelsi Côgo de Sá3 \\ Recebido em 23 junho, 2006 / Aceito em 27 setembro, 2006 \\ Received on June 23, 2006 / Accepted on September 27, 2006
}

\begin{abstract}
A new gravity survey was conducted between coordinates $39^{\circ}$ to $49^{\circ} \mathrm{W}$ and $17^{\circ}$ to $23^{\circ} \mathrm{S}$ in SE São Francisco Craton. A total of 176 new gravity stations was obtained. The position of each gravity station was determined using GPS (Global Positioning System) relative positioning method. The new data was added to the gravity data-bank of IAG (Instituto de Astronomia, Geofísica e Ciências Atmosféricas)/USP (Universidade de São Paulo). A total of 12,339 stations was processed and interpreted. The geology of this area is represented by Archean and Proterozoic metamorphic terrains of SE São Francisco Craton, including the Araçuaí and Ribeira fold/thrust belts. In order to separate shallow from deep sources of gravity field, a $50 \mathrm{~km}$ upward continued regional field was removed from Bouguer anomaly map. The residual gravity field from the Quadrilátero Ferrifero was correlated with the exposed geological units. The main gravity anomalies were forward modeled in order to map the contact between the main metamorphic complexes. Metamorphic complexes in this area have distinct gravity signatures. Bação and Caeté metamorphic complexes have negative gravity anomalies with similar amplitude. Bonfim metamorphic complex has positive gravity anomalies and its limits extend beyond the geologically mapped area, under younger sedimentary sequences. Forward gravity modeling constrained by observed geological contacts allowed to estimate the directions and dips of two major tectonic contacts. The contact between Barbacena and Bonfim metamorphic complexes dips $21^{\circ}$ northward, whereas Belo Horizonte complex dips $31^{\circ}$ westward under the Rio das Velhas supergroup.
\end{abstract}

Keywords: gravity, gravity anomalies, iron formation, São Francisco Craton.

RESUMO. Um novo levantamento gravimétrico foi realizado na região delimitada pelas coordenadas $39^{\circ}$ a $49^{\circ} \mathrm{W}$ e $17^{\circ}$ a $23^{\circ} \mathrm{S}$. Foram coletados 176 novos dados gravimétricos, localizados na parte SE do Cráton São Francisco. As estações gravimétricas foram posicionadas por GPS (Global Positioning System), através do modo relativo estático. Os novos dados foram adicionados ao banco de dados gravimétricos do IAG/USP. Assim, 12.339 dados gravimétricos foram processados e interpretados. A geologia da área é representada pelos terrenos metamórficos arqueanos e proterozóicos do sudeste do Cráton São Francisco, incluindo as faixas de dobramentos Araçuaí e Ribeira. Para separar fontes rasas de fontes profundas do campo gravimétrico, o campo regional continuado para cima à altura de $50 \mathrm{~km}$ foi removido das anomalias Bouguer. 0 campo gravimétrico residual do Quadrilátero Ferrífero foi correlacionado com as unidades geológicas aflorantes. Os complexos metamórficos existentes nessa região possuem assinaturas gravimétricas distintas. Os complexos metamórficos Bação e Caeté possuem anomalias gravimétricas negativas com amplitudes muito próximas. 0 complexo metamórfico Bonfim possui anomalias gravimétricas positivas e seus limites estendem-se além da área mapeada pela geologia de superfície, sob sequeências sedimentares mais jovens. Modelagem gravimétrica direta utilizando como vínculos os contatos geológicos aflorantes permitiu estimar as direções e mergulhos de dois contactos tectônicos importantes. 0 contato entre os complexos de Barbacena e Bonfim tem mergulho de $21^{\circ}$ para norte, enquanto 0 complexo Belo Horizonte mergulha com ângulo de $31^{\circ}$ para oeste sob o Supergrupo Rio das Velhas.

Palavras-chave: gravimetria, anomalias gravimétricas, Quadrilátero Ferrífero, Cráton São Francisco.

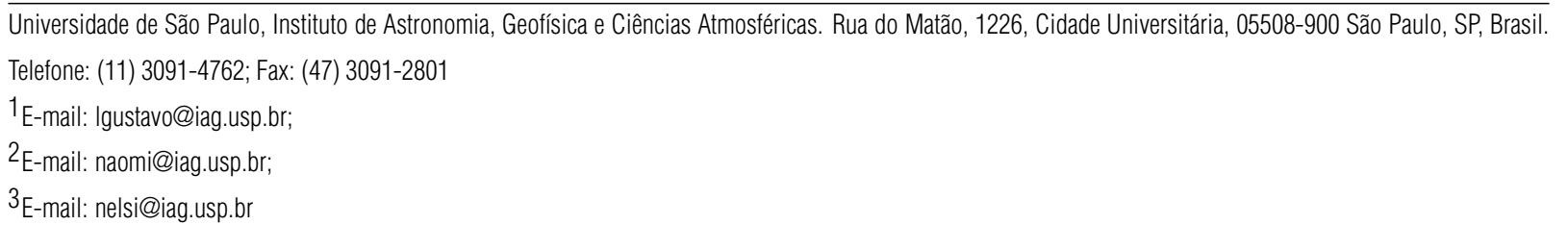




\section{INTRODUÇÃO}

Apesar do amplo acervo de dados geológicos no SE do Cráton São Francisco, poucos são os trabalhos geofísicos de detalhe que objetivam um melhor conhecimento das estruturas crustais rasas e profundas da região. Blitzkow et al. (1979) apresentaram um primeiro modelo da estrutura crustal do sudeste do estado de Minas Gerais a partir da modelagem de dados gravimétricos, utilizando como vínculo na modelagem, o resultado da sísmica de refração. A espessura crustal nessa região foi estimada entre $38 \mathrm{e}$ 40 km. França \& Assumpção (2004) estimaram a espessura crustal através da técnica sismológica da função do receptor, obtendo para a região sul do Cráton São Francisco espessuras da crosta entre 37 e 42 km. Teixeira et al. (2000) faz referência sobre os modelos de origem e evolução do Quadrilátero Ferrífero.

Há vários modelos sobre a origem e justaposição do cinturão "greenstone" Rio das Velhas com a crosta siálica do Quadrilátero Ferrífero. 0 objetivo do presente estudo geofísico é fornecer dados adicionais que auxiliem na definição entre dois possíveis modelos, como propostos por Carneiro (1992). 0 primeiro modelo estaria condicionado a colisão ou amalgamento de dois ou mais protocontinentes (exemplos: complexos metamórficos Bonfim, Belo Horizonte, Caeté) com um segmento de crosta oceânica (exemplo: Cinturão "greenstone" Rio das Velhas). A idade mínima deste evento estaria balizada pelos resultados $\mathrm{U} / \mathrm{Pb}$ de 2,78 Ga, encontrados no âmbito do complexo metamórfico Bonfim Setentrional.

Já o segundo modelo relaciona-se a uma ruptura crustal de massa siálica pré-existente, ou de micro-continente do Arqueano Médio. Estas rupturas teriam proporcionado a instalação de bacias sedimentares intracontinentais (ou "intracratônicas"), interligadas e de pequena monta. A partir daí ocorreria uma invasão transcontinental e a extrusão precoce de material mantélico máfico-ultramáfico, ao longo de fissuras transcrustais. No decorrer de sua evolução geológica estas bacias aportaram uma variada seqüência supracrustal, de modo a constituir 0 atual cinturão do tipo "greenstone".

Neste artigo, serão apresentados os resultados da análise semiquantitativa dos dados gravimétricos do Quadrilátero Ferrífero (linha tracejada azul, Fig. 1) e uma correlação desses dados com a geologia local visando auxiliar o mapeamento dos limites dos diversos complexos metamórficos que o compõem.

\section{METODOLOGIA DE COLETA DOS DADOS}

\section{Posicionamento geográfico e vertical}

Os mapas topográficos (escala 1:50.000) do SE do Cráton São Francisco foram publicados na década de 1970, estão desatualizados e não permitem a obtenção das coordenadas das estações gravimétricas com precisão menor que $\pm 500 \mathrm{~m}$. A região de estudo é caracterizada por forte variação topográfica. A necessidade de se obter a altitude ortométrica com erro menor do que $\pm 0,5 \mathrm{~m}$ para a redução dos dados de gravimetria regional dificulta a utilização do nivelamento barométrico. Desta forma, optou-se pela utilização do GPS (Global Positioning System) para o posicionamento relativo das estações gravimétricas.

0 posicionamento relativo por GPS pode ser realizado em tempo real ou por meio do pós-processamento. 0 primeiro é complicado por envolver comunicação de dados entre o receptor da base e o receptor móvel através de rádio, o que significa equipamento adicional. 0 segundo, além de ser mais simples do ponto de vista operacional, é mais preciso. Portanto, optou-se pelo posicionamento relativo pós-processado.

No posicionamento relativo pós-processado, um receptor é instalado em um ou mais pontos nos quais as coordenadas são conhecidas, que neste caso foram as estações da RBMC-IBGE (Rede Brasileira de Monitoramento Contínuo do IBGE), que constituíram as bases para o levantamento. 0 receptor móvel foi instalado nos pontos a serem posicionados e coletou dados GPS durante 15 minutos. Após completar a coleta dos dados, os arquivos armazenados no receptor foram transferidos para um computador para um processamento básico e cálculo das coordenadas geométricas.

Uma descrição mais detalhada da metodologia utilizada na aquisição e posicionamento dos dados de posicionamento através do GPS é encontrada em Santos (2005). No posicionamento das estações gravimétricas foi usado um receptor GPS ASHTECH, modelo Z-12. No pós-processamento relativo foram fixadas 4 bases da RBMC localizadas, nas cidades do Rio de Janeiro (RJ), Presidente Prudente (SP), Viçosa (MG) e Brasília (DF). Assim, foi possível ajustar a rede de pontos. Com isso, foi possível obter precisões da ordem de $\pm 30 \mathrm{~cm}$ nas coordenadas geodésicas (latitude, longitude e altitude ortométrica).

As altitudes ortométricas das estações gravimétricas implantadas foram determinadas a partir das altitudes geométricas, obtidas por GPS, e do modelo geoidal gravimétrico existente para a região (Santos, 2005), usando o método relativo. 0 erro máximo resultante é $50 \mathrm{~cm}$.

Essas incertezas, quando propagadas para a redução dos dados gravimétricos, correspondem a um erro inferior a $\pm 0,1 \mathrm{mGal}$ no valor final da anomalia Bouguer.

\section{Gravimetria}

A aquisição e processamento de dados gravimétricos seguem os procedimentos descritos em Sá et al. (1993) e Sá (1994). Tendo em vista uma melhor distribuição geográfica dos dados 


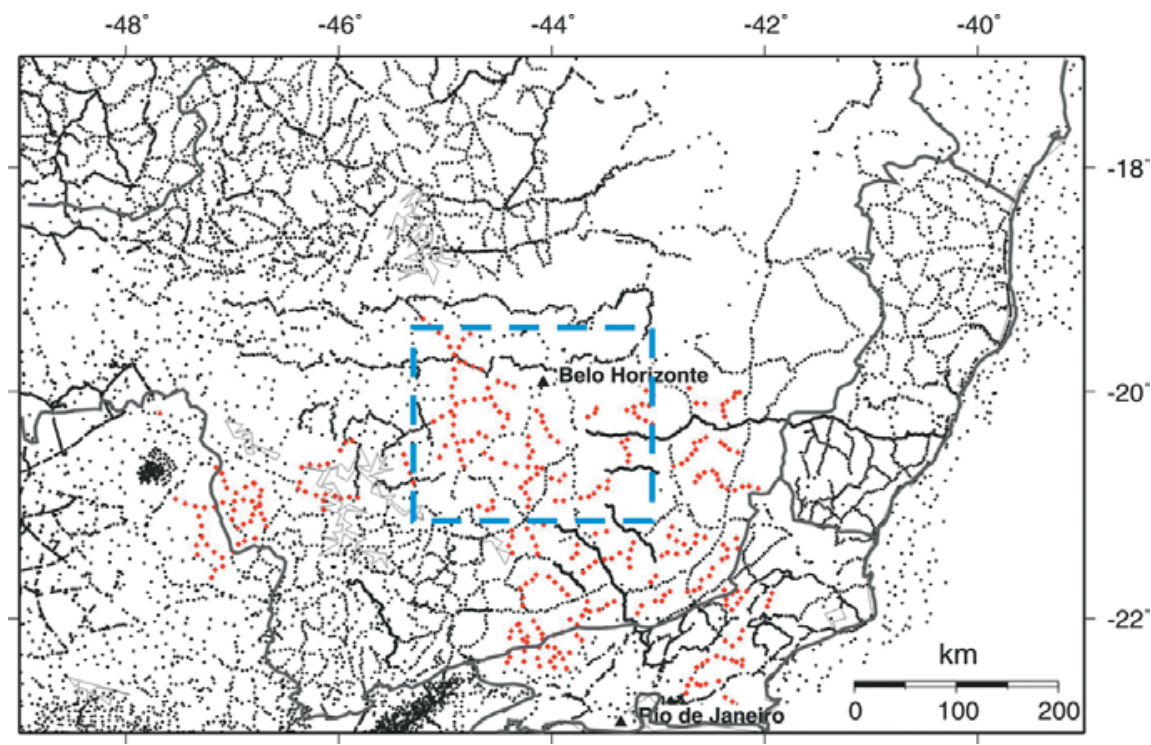

Figura 1 - Localização das estações gravimétricas e magnetotelúricas na área de estudo. Pontos pretos: Estações gravimétricas do banco de dados do IAG-USP até setembro de 2002; Pontos vermelhos: Estações gravimétricas obtidas pelo IAG-USP em setembro de 2002 e março de 2003; Contorno cinza: Divisão política estadual. Linha tracejada azul: Área de estudo.

Satélites

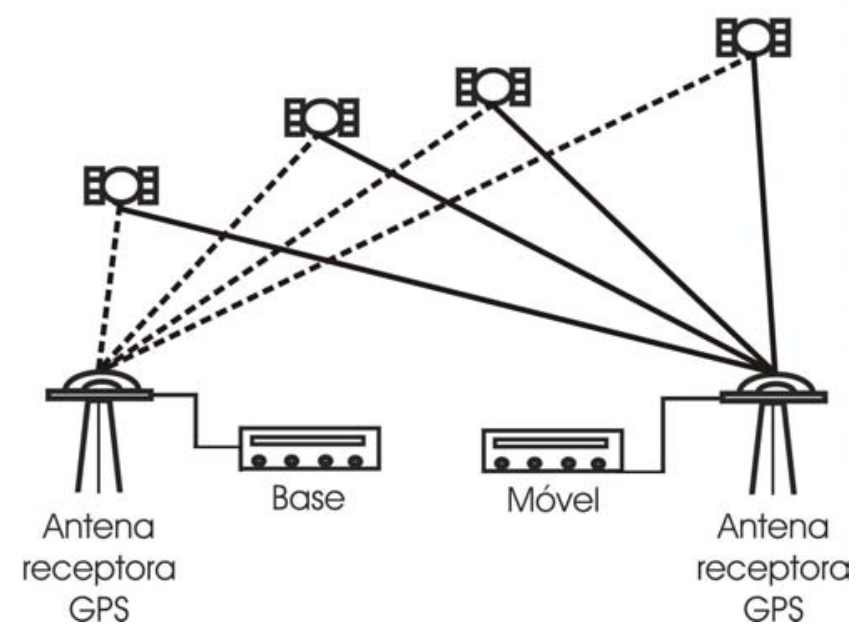

Figura 2 - Representação do mecanismo de funcionamento do posicionamento (GPS).

gravimétricos do sudeste do Cráton São Francisco, foram realizadas duas campanhas gravimétricas, uma em setembro de 2002, e outra em março de 2003. As campanhas tiveram como objetivo complementar 0 sul do estado de Minas Gerais, principalmente 0 Quadrilátero Ferrífero, e a região norte do estado de São Paulo. Foram coletadas 176 novas estações gravimétricas que adicionadas às outras 12.163 existentes no banco de dados gravimétricos do IAG, resultam na cobertura mostrada na Fig. 1. Todos os da- dos aqui utilizados são públicos e disponíveis por solicitação aos autores.

0 ponto de partida da campanha gravimétrica foi a cidade de Vassouras (RJ), onde se localiza o Observatório Magnético do ON (Observatório Nacional)/MCT (Ministério da Ciência e Tecnologia). A distância média entre as estações gravimétricas é em média $10 \mathrm{~km}$. A precisão das medidas gravimétricas é $\pm 0,01 \mathrm{mGal}$. 


\section{Mapas de anomalias Bouguer regional e residual}

A Figura 3 mostra o mapa de anomalias Bouguer resultante da interpolação dos dados mostrados na Figura 1. 0 método de interpolação utilizado foi o de mínima curvatura, com uma grade de $5 \mathrm{~km} \times 5 \mathrm{~km}$. Observa-se no mapa províncias gravimétricas distintas que se correlacionam diretamente com as principais feições tectônicas, como o Cráton São Francisco, com anomalias gravimétricas que variam entre -100 e -80 mGal, Bacia do Paraná com anomalias entre -90 e -40 mGal, Faixa Ribeira que apresenta um forte gradiente gravitacional em direção à crosta oceânica e 0 Quadrilátero Ferrífero que se destaca no interior do Cráton São Francisco como uma anomalia gravimétrica circular de amplitude da ordem de -85 a -70 mGal.

0 procedimento usual na interpretação gravimétrica é a separação das anomalias de origem profundas e rasas. Neste trabalho utilizou-se como método de separação de anomalias gravimétricas profundas e rasas, o campo regional previsto pela continuação para cima. A Figura 4 mostra 0 mapa da componente regional para a altitude de continuação de $50 \mathrm{~km}$. Neste mapa estão presentes as anomalias gravimétricas de longo comprimento de onda e origem profunda, possivelmente na interface crosta-manto. A escolha do valor de altitude de continuação de $50 \mathrm{~km}$ é justificada pela pequena variação do campo gravitacional de grande comprimento de onda quando esta altitude varia entre $50 \mathrm{~km}$ e altitudes maiores. Para altitude menor que $50 \mathrm{~km}$ observam-se anomalias gravimétricas de curto comprimento de ondas, originadas de fontes mais rasas e correlacionadas com feições geológicas na superfície.

0 mapa residual (Fig. 5) foi obtido através da subtração entre o mapa das anomalias Bouguer (Fig. 3) e a continuação para cima de 50 km (Fig. 4).

\section{Anomalias gravimétricas residuais}

A Figura 5 mostra as anomalias gravimétricas residuais do SE do Cráton São Francisco. Dentro da região delimitada pelo retângulo tracejado (Quadrilátero Ferrífero) predominam anomalias gravimétricas positivas com uma amplitude máxima de $10 \mathrm{mGal}$. Na Figura 6, as anomalias gravimétricas do Quadrilátero Ferrífero são mostradas em maior detalhe. As idades das rochas indicadas na Figura 6 são aquelas compiladas em Teixeira et al. (1996). Estas rochas possuem idades com valores situados entre 1,9 e 2,86 Ga.

É notória na Figura 6 a distribuição das anomalias gravimétricas residuais em duas principais províncias gravimétricas. A província com anomalias positiva localiza-se na região na parte central e oeste enquanto que a província com anomalias negativas localiza-se a leste e na porção sul do Quadrilátero Ferrífero.

\section{A geologia do Quadrilátero Ferrífero}

A região meridional do Cráton São Francisco pode ser dividida em quatro grandes unidades litoestratigráficas segundo Carneiro (1992), Tabela 1.

Na Figura 7 são apresentadas as principais unidades geológicas do Quadrilátero Ferrífero, modificadas de Carneiro et al. (1998).

Os complexos metamórficos presentes na região do Quadrilátero Ferrífero possuem uma composição parecida, ou seja, são constituídos por rochas gnáissicas poli-deformadas de composição tonalítica a granítica e subordinadamente por granitos, granodioritos, anfibolitos e intrusões máfica a ultramáfica.

0 complexo metamórfico presente na área do Quadrilátero Ferrífero não possui uma divisão formal. São utilizadas divisões geográficas na identificação de alguns de seus setores, de acordo com Carneiro (1992). Destacam-se neste contexto os complexos metamórficos de Bação, Caeté, Belo Horizonte e Congonhas.

Ainda segundo Carneiro (1992), o complexo metamórfico Bonfim possui os limites ocidental e meridional definidos de forma imprecisa, e suas relações com os demais complexos metamórficos do Quadrilátero Ferrífero e suas adjacências são igualmente pouco conhecidas.

A região onde está inserido o Quadrilátero Ferrífero foi palco de vários eventos geodinâmicos que se processaram durante o Arqueano e o Proterozóico. Processos estes marcados pela manifestação de intensa atividade de deformação, retrabalhamento e acresção crustal (Teixeira et al., 1996).

\section{Análise dos resultados das anomalias gravimétricas residuais}

Analisando os resultados apresentados nas Figs. 6 e 7, vemos uma correlação direta existente entre as anomalias gravimétricas e os complexos metamórficos que constituem o embasamento.

0 complexo metamórfico Belo Horizonte (região I, Fig. 7) apresenta anomalias gravimétricas tanto positivas quanto negativas. Em sua grande parte, a variação de amplitude é de cerca de 4 mGal.

0 complexo metamórfico Bonfim (região II, Fig. 7) é caracterizado por apresentar anomalias gravimétricas positivas, com uma variação de amplitude de cerca de $12 \mathrm{mGal}$. Em vários pontos este complexo é coberto por rochas supracrustais de natureza vulcano-sedimentar (Supergrupo Rio das Velhas).

De acordo com os dados gravimétricos, o complexo metamórfico Bação não ocorre apenas na região III da Fig. 7, como sugerido por Carneiro (1992), mas deve incluir também o complexo metamórfico Caeté, região V da Fig. 7. Constituindo-se em 


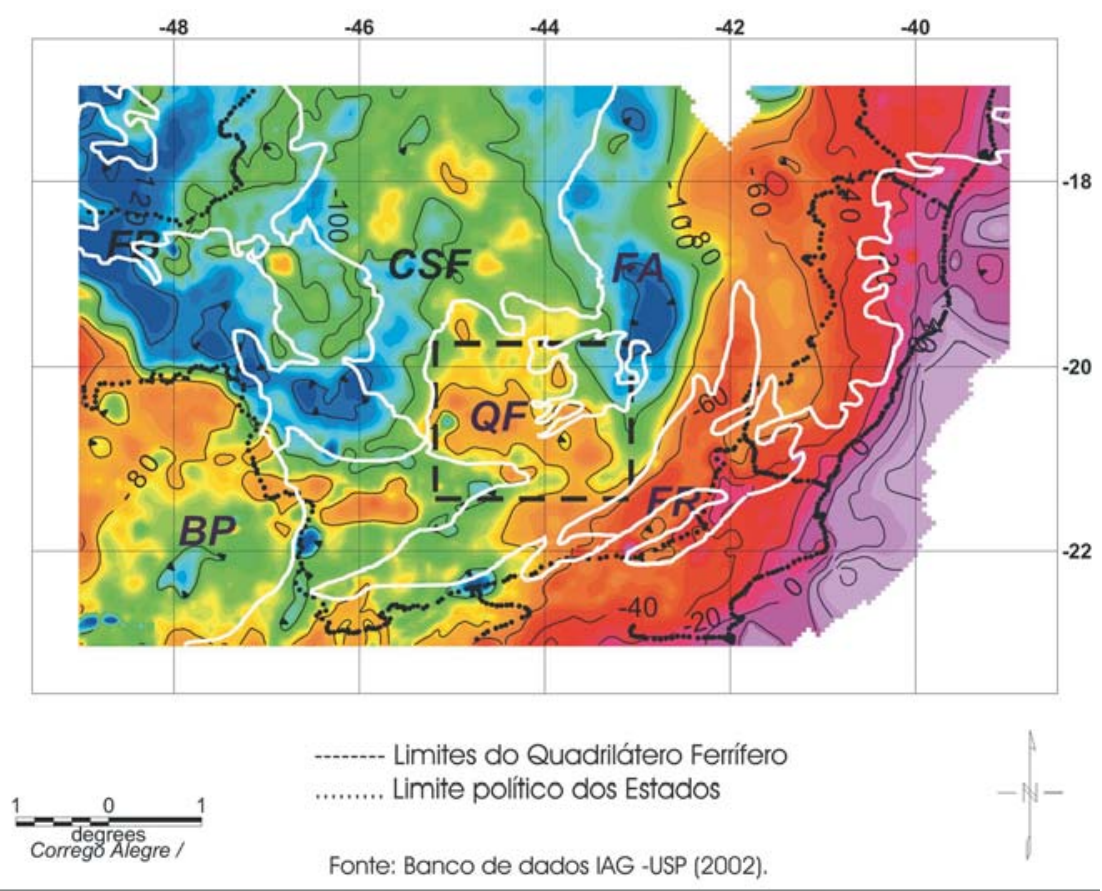

Figura 3 - Anomalias Bouguer simples do sudeste do Cráton São Francisco. Intervalo de contorno 20 mGal. As linhas em branco são os contornos das principais estruturas geológicas do local. Onde: $F B$ é a faixa Brasília; $B P$ é a bacia do Paraná; CSF é o Cráton São Francisco; FA é a faixa Araçuaí; FR é a faixa Ribeira e QF é 0 Quadrilátero Ferrífero.

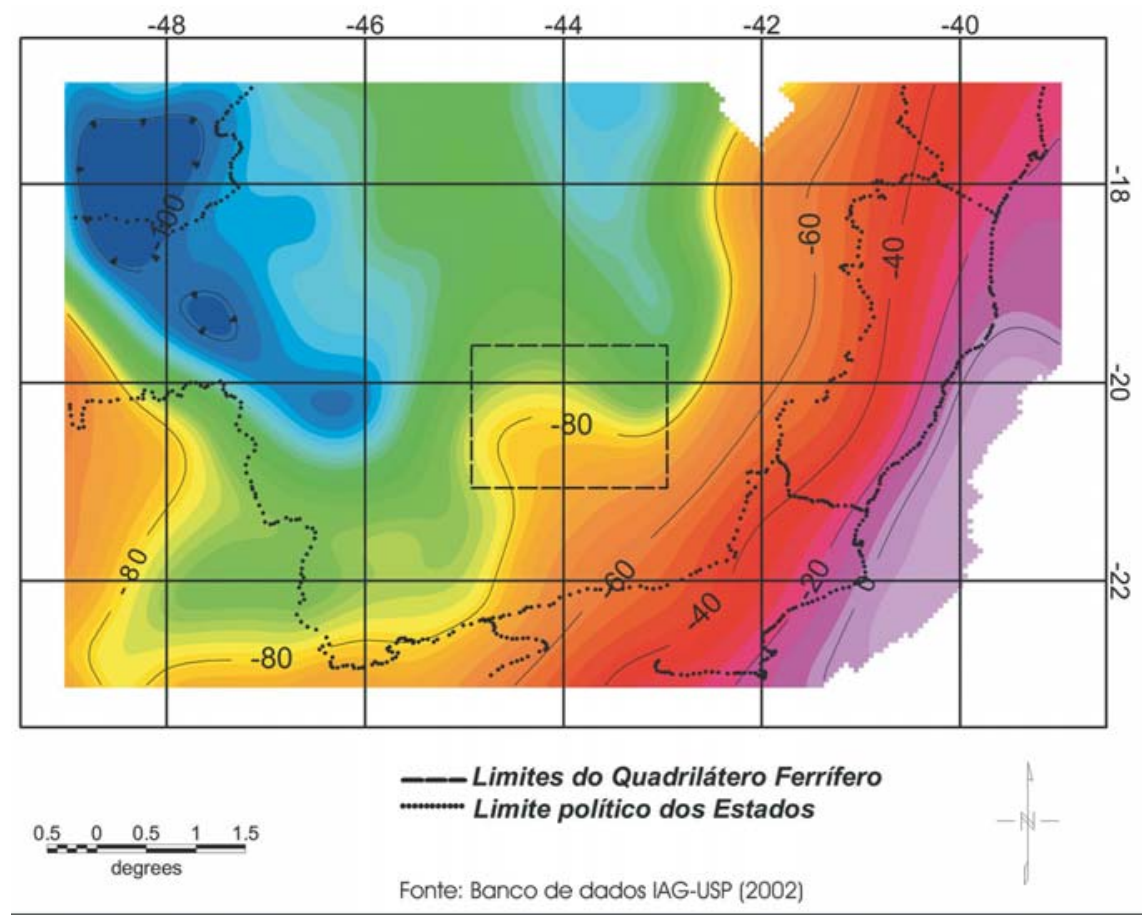

Figura 4 - Anomalias Bouguer regional, obtida através da continuação para cima de 50 km. Intervalo de contorno 20 mGal. 


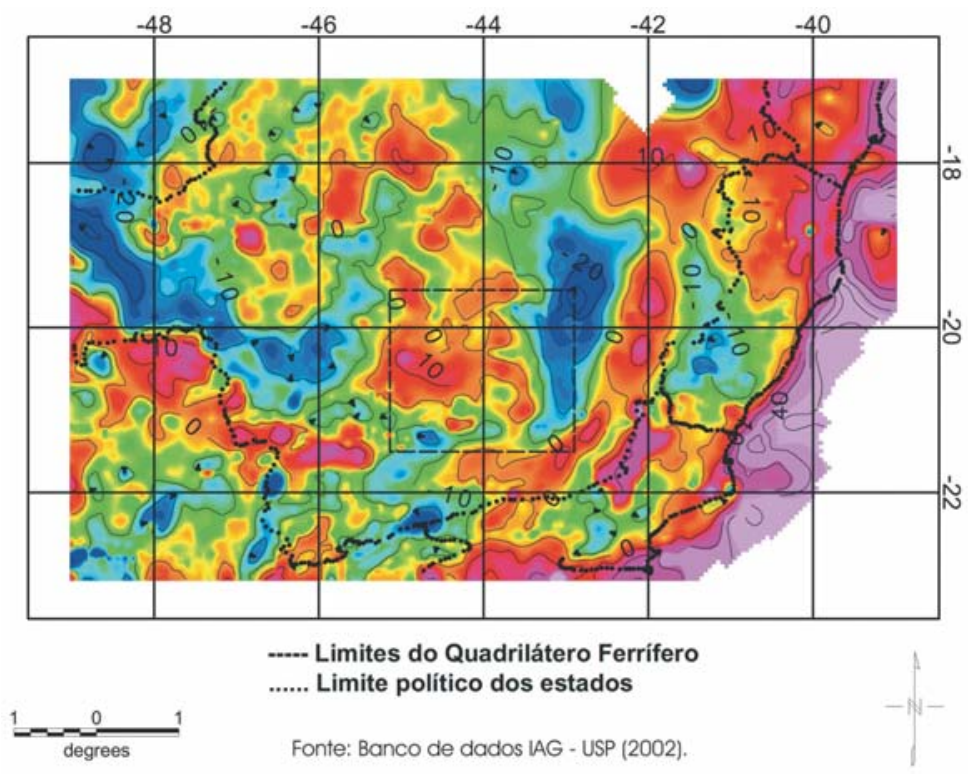

Figura 5 - Anomalias Bouguer residuais subtraindo-se a continuação para cima de $50 \mathrm{~km}$ do mapa de anomalias Bouguer mostrado na Figura 3. Intervalo de contorno 10 mGal. 0 retângulo tracejado corresponde ao Quadrilátero Ferrífero.

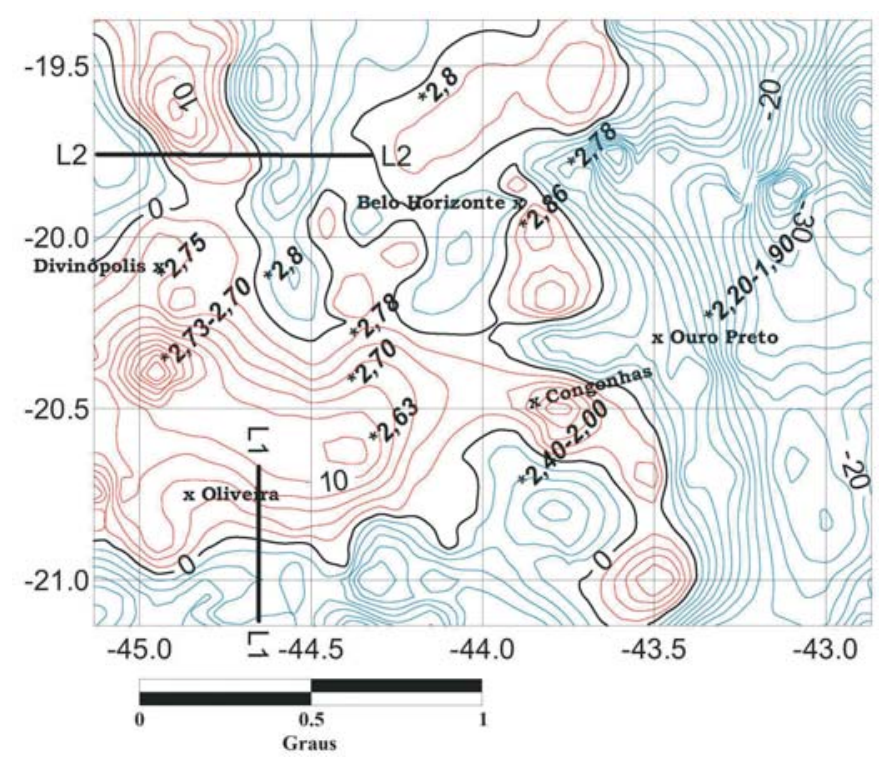

Figura 6 - Curvas de contorno da anomalia gravimétrica Bouguer residual para a região do Quadrilátero Ferrífero. As linhas em vermelhos são valores positivos, as linhas em azul negativo e as linhas em preto têm valor zero. Intervalo de contorno 2 mGal. Os perfis L1 e L2 foram modelados. 0 símbolo * indica a idade (em Ga).

um único corpo com a mesma assinatura gravimétrica, ou seja, anomalias essencialmente negativas, variando em torno do valor de -6 mGal e com amplitude de 4 mGal.

0 complexo metamórfico Congonhas (região IV, Fig. 7) apresenta anomalias gravimétricas essencialmente negativas com amplitude da ordem de 8 mGal.

\section{Modelagem de perfis gravimétricos residuais}

Dois perfis gravimétricos foram escolhidos (L1 e L2 na Fig. 6) para estimar a relação de contato entre os principais complexos metamórficos. 0 primeiro perfil L1 é um perfil S-N, localizado na região sudoeste do Quadrilátero Ferrífero. Este perfil está lo- 
Tabela 1 - Litoestratigrafia do SE do Cráton São Francisco segundo Carneiro (1992).

\begin{tabular}{|c|c|c|c|}
\hline Unidades Informais & Distribuição & Natureza & Idade \\
\hline $\begin{array}{l}\text { Coberturas sedimentares } \\
\text { predominantemente } \\
\text { sem metamorfismo } \\
\text { (ex. Supergrupo } \\
\text { São Francisco) }\end{array}$ & $\begin{array}{l}\text { Amplo desenvolvimento a } \\
\text { noroeste e norte da porção } \\
\text { meridional do cráton. }\end{array}$ & $\begin{array}{l}\text { Essencialmente sedimentar } \\
\text { com metamorfismo e } \\
\text { deformação nas porções } \\
\text { marginais (essencialmente } \\
\text { da borda oriental). }\end{array}$ & Proterozóico Superior \\
\hline $\begin{array}{c}\text { Seqüências sedimentares } \\
\text { metamorfizadas } \\
\text { (ex. Supergrupo } \\
\text { Espinhaço e Minas) }\end{array}$ & $\begin{array}{l}\text { Restrita, desenvolvendo-se } \\
\text { preferencialmente no } \\
\text { Quadrilátero Ferrífero com } \\
\text { distribuição para Norte e } \\
\text { Sudoeste. }\end{array}$ & $\begin{array}{c}\text { Espesso pacote } \\
\text { metassedimentar com } \\
\text { distribuição vulcânica e com } \\
\text { metamorfismo da fácies } \\
\text { xisto verde. }\end{array}$ & $\begin{array}{l}\text { Proterozóico Médio/ } \\
\text { Proterozóico Inferior }\end{array}$ \\
\hline $\begin{array}{c}\text { Seqüências vulcano- } \\
\text { sedimentar metamorfizadas } \\
\text { (ex. Supergrupo } \\
\text { Rio das Velhas) }\end{array}$ & $\begin{array}{l}\text { Restrita, desenvolvendo-se } \\
\text { preferencialmente no } \\
\text { Quadrilátero Ferrífero com } \\
\text { com distribuição } \\
\text { para Norte e } \\
\text { Sudoeste. }\end{array}$ & $\begin{array}{l}\text { Espesso pacote vulcano- } \\
\text { sedimentar do tipo } \\
\text { "greenstone" belt, muito } \\
\text { deformado com } \\
\text { metamorfismo de fácies } \\
\text { xisto verde. }\end{array}$ & Arqueano \\
\hline Complexos metamórficos & $\begin{array}{l}\text { Ampla, desenvolve por } \\
\text { toda a porção meridional } \\
\text { do cráton. }\end{array}$ & $\begin{array}{c}\text { Dominantemente } \\
\text { metamórfica, com intrusões } \\
\text { associadas e variada } \\
\text { composição. Metamorfismo } \\
\text { variado das fácies granito a } \\
\text { xisto verde com paragêneses } \\
\text { retrometamórficas. }\end{array}$ & Arqueano \\
\hline
\end{tabular}

calizado na Figura 8. 0 Grupo Barbacena, que localiza-se a sul do complexo metamórfico Bonfim, tem densidade $0,04 \mathrm{~g} / \mathrm{cm}^{3}$ menor que o complexo metamórfico Bonfim. Usando como vínculo 0 contato geológico aflorante na posição de $\mathrm{x}=20 \mathrm{~km}$, a modelagem gravimétrica mostra que 0 contato entre as rochas do Grupo Barbacena e rochas do complexo Bonfim mergulha para norte com ângulo de $21^{\circ}$ (Fig. 8).

0 segundo perfil L2 é um perfil leste-oeste, localizado na região noroeste do Quadrilátero Ferrífero. As anomalias gravimétricas do perfil foram modeladas (Fig. 9) utilizando quatro blocos com densidades distintas.

Nesta modelagem, o complexo metamórfico Belo Horizonte possui uma densidade $0,04 \mathrm{~g} / \mathrm{cm}^{3}$ menor que 0 Supergrupo Rio das Velhas. Fixando-se os limites dos afloramentos dos diferentes blocos, pode-se inferir que os blocos apresentam um merguIho para oeste de $31^{\circ}$ apresentados na Figura 9.

Os corpos denominados como embasamento granito-gnáissico indiviso (1) e (2) em diversas fontes da literatura (Schobbenhaus et al., 1984; Teixeira et al., 2000) apresentam-se como sendo um único corpo, ou seja, corpo indiviso. Porém através dos dados gravimétricos podemos verificar que existe uma diferença nos valores das anomalias gravimétricas (aproximadamente $0,013 \mathrm{~g} / \mathrm{cm}^{3}$ ), indicando valores diferentes de densidade para os mesmos. Isso provavelmente estaria indicando as diferenças de metamorfismo sofrida pelas duas regiões durante a história geológica.

\section{DISCUSSÃO}

De acordo com a compilação de dados geocronológicos de Endo \& Machado (2002), os complexos metamórficos presentes nesta região possuem uma idade de formação no intervalo de 2,7 e 2,5 Ga, e composição similar, o que justificaria as pequenas diferenças existentes nas anomalias gravimétricas. Porém os eventos geotectônicos que ocorreram durante toda a história do sudeste do Cráton São Francisco afetaram esta região de maneira não uniforme e em idades distintas, principalmente os eventos: Transamazônico (2100-1700 Ma) e Brasiliano (650-500 Ma).

Os eventos geotectônicos poderiam ter ocasionado essas pequenas diferenças nos valores das anomalias gravimétricas, uma 


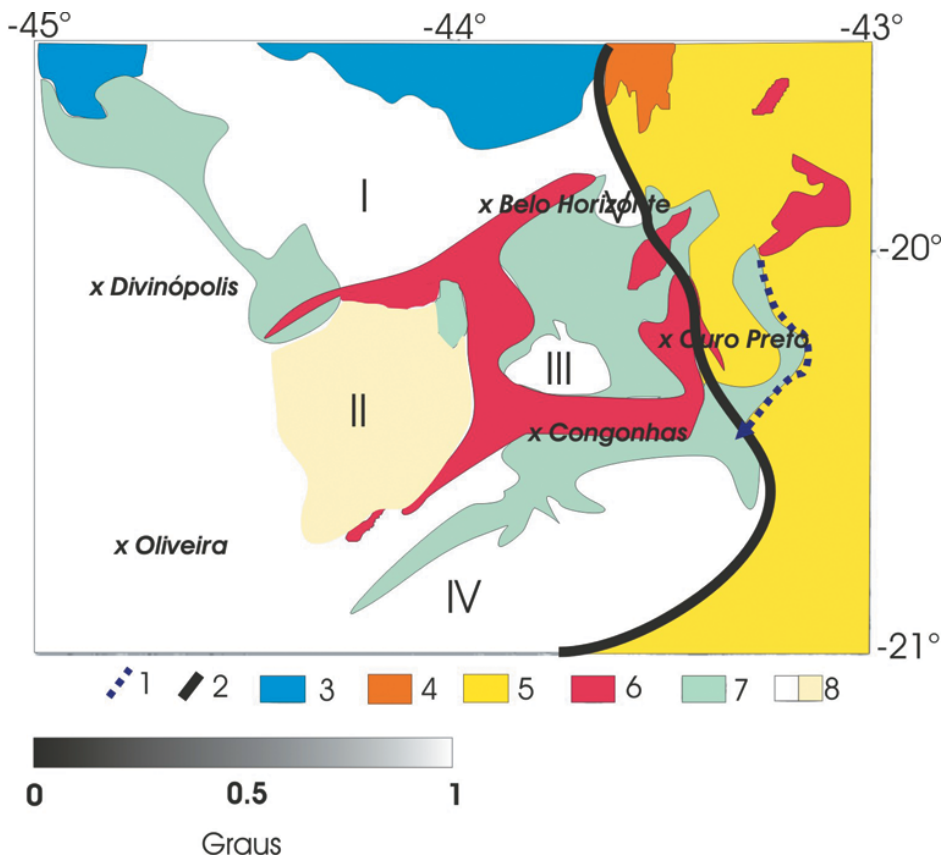

Figura 7 - Geologia do Cráton São Francisco Meridional (modificado de Carneiro et al., 1998). Símbolos: 1 - Empurrão; 2 - Limite cratônico oriental; 3 - Supergrupo São Francisco; 4 - Supergrupo Espinhaço; 5 - Complexo metamórfico formado ou retrabalhado no Neoproterozóico; 6 - Supergrupo Minas; 7 - Supergrupo Rio das Velhas; 8 - Complexos metamórficos arqueano (I - Belo Horizonte; II - Complexo metamórfico Bonfim; III - Bação; IV - Congonhas; V - Caeté).

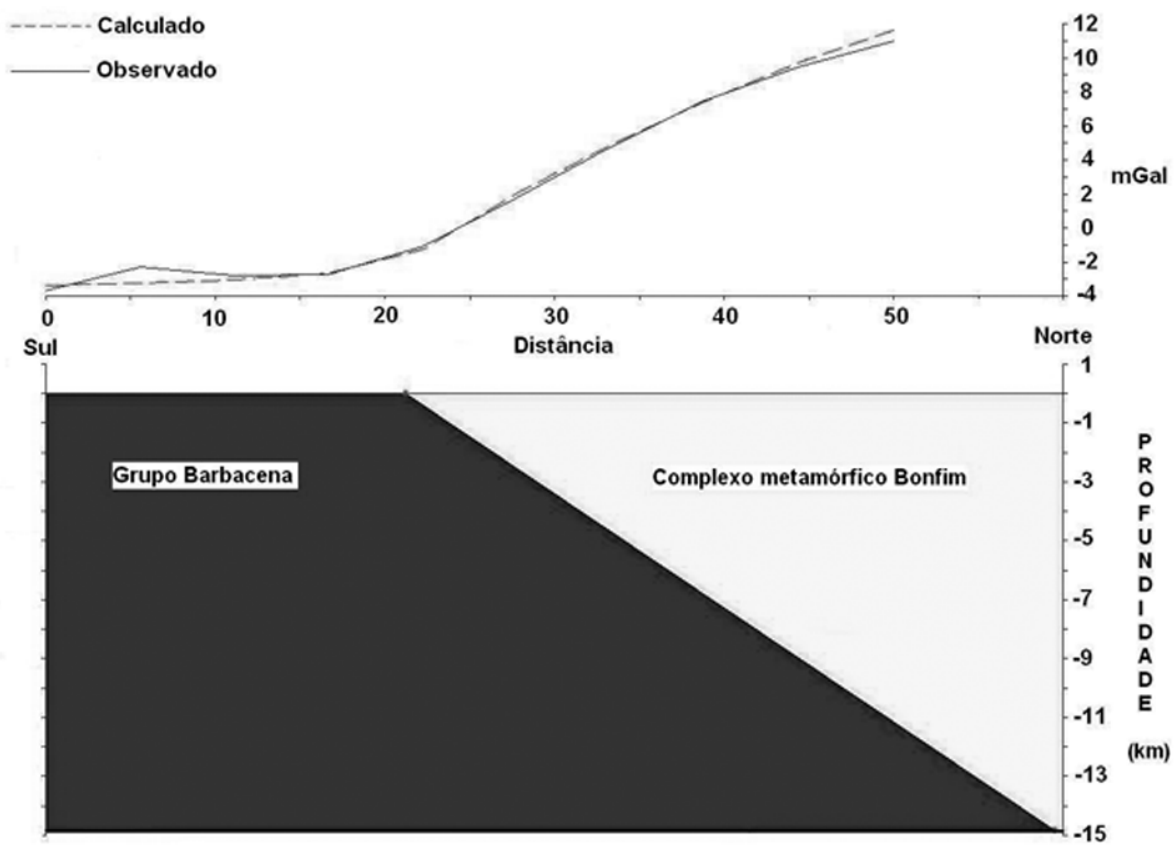

Figura 8 - Figura mostrando um perfil S-N, perfil L1 da Figura 6 e a modelagem realizada utilizando 0 algoritmo de Talwani et al. (1959). 0 complexo metamórfico Bonfim é mais denso que o Grupo Barbacena em 0,04 g/ $/ \mathrm{cm}^{3}$. 


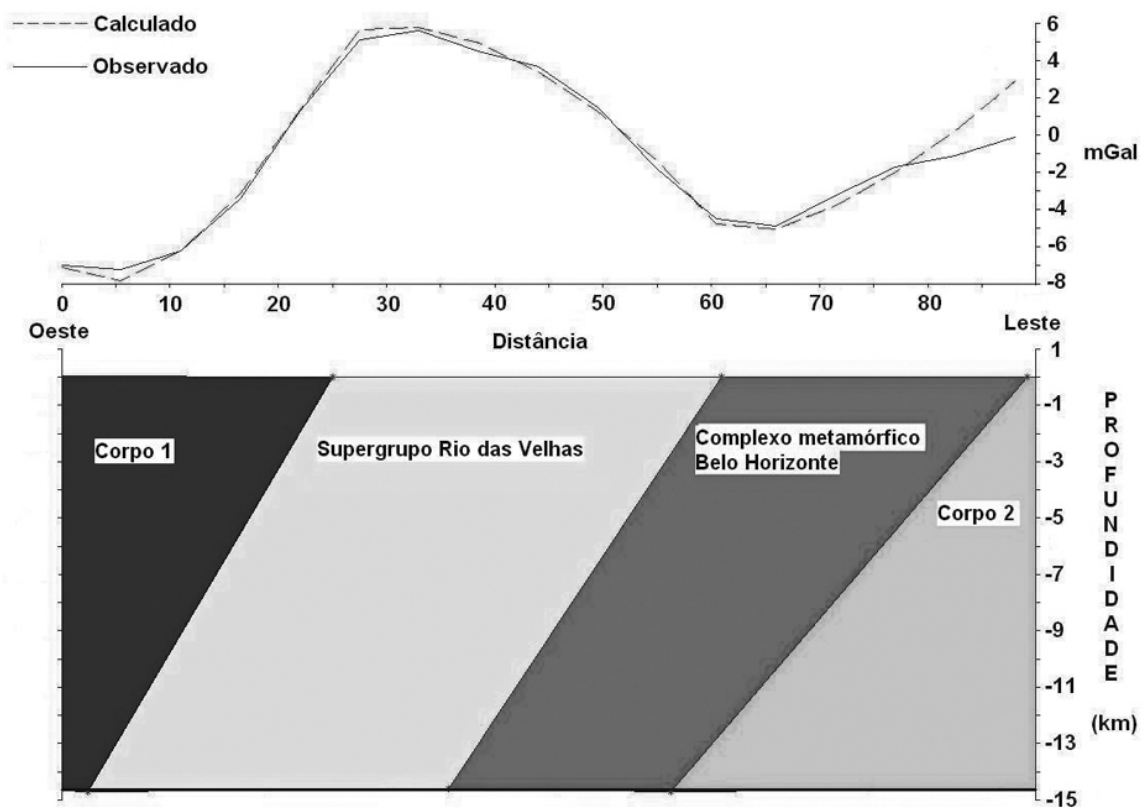

Figura 9 - Figura mostrando um perfil W-E, perfil L2 da Figura 6 e a modelagem realizada utilizando 0 algoritmo de Talwani et al. (1959). 0 Supergrupo Rio das Velhas é mais denso $0,04 \mathrm{~g} / \mathrm{cm}^{3}$ em relação ao complexo Belo Horizonte. Os corpos do embasamento granito-gnáissico (1) e (2) na literatura geológica apresentam-se como sendo indivisos, porém gravimetricamente possuem diferenças de aproximadamente $0,013 \mathrm{~g} / \mathrm{cm}^{3}$.

vez que os mesmos afetaram mais fortemente a parte leste do Quadrilátero Ferrífero, segundo Chemale et al. (1994). Anomalias gravimétricas predominantemente negativas correlacionam com granitóides resultantes do rejuvenescimento crustal da área, com refusão de parte da crosta durante evento térmico.

Através dos dados geofísicos de gravimetria foi possível comprovar a hipótese de Carneiro (1992), que sugere uma mesma origem para os diversos complexos metamórficos localizados no Quadrilátero Ferrífero, uma vez que, os complexos metamórficos de Bação, Belo Horizonte, Caeté e Congonhas apresentam a mesma assinatura gravimétrica, com anomalias gravimétricas essencialmente negativas e com amplitude das anomalias aproximadamente de $6 \mathrm{mGal}$, 0 que indicaria a origem comum dos complexos metamórficos citados acima.

0 complexo metamórfico Bonfim é, do ponto de vista gravimétrico, completamente distinto dos demais complexos metamórficos da área devido ao caráter estritamente positivo das suas anomalias gravimétricas. Seus limites avançam sob regiões cobertas por seqüências sedimentares mais jovens, mostrando a utilidade dos levantamentos gravimétricos no mapeamento desses corpos.

Com a modelagem direta dos perfis gravimétricos e utilizando a localização dos contatos dos geológicos como vínculos, foi possível inferir o mergulho dos contatos entre os complexos metamórficos, o que pode ser de fundamental importância do ponto de vista estrutural e exploratório.

0 mergulho estimado entre 0 Grupo Barbacena e o complexo metamórfico Bonfim é de aproximadamente $21^{\circ}$. 0 ângulo de mergulho estimado entre o Supergrupo Rio das Velhas e 0 complexo metamórfico Belo Horizonte é de aproximadamente $31^{\circ}$.

\section{CONCLUSÕES}

0 método GPS para o posicionamento das estações gravimétricas mostrou-se bastante rápido e preciso para a obtenção das coordenadas das estações gravimétricas na área de estudo, caracterizada por forte gradiente topográfico. 0 método possibilitou a obtenção das coordenadas das estações com precisão de $\pm 10 \mathrm{~cm}$ nas coordenadas horizontais e de $\pm 30 \mathrm{~cm}$ no posicionamento vertical.

Com os novos dados gravimétricos foi possível testar as duas hipóteses propostas por Carneiro (1992) sobre a origem e justaposição do cinturão "greenstone" Rio das Velhas com a crosta siálica. Os dados gravimétricos obtidos favorecem o modelo segundo o qual os diversos complexos metamórficos presentes na região do Quadrilátero Ferrífero teriam uma mesma origem, ou seja, teriam se originados da ruptura crustal de massa 
siálica pré-existente, ou de micro-continente do Arqueano Médio, e posteriormente a formação dos cinturões "greenstone".

Com a modelagem gravimétrica direta, foi possível estabelecer a relação de contato entre os diversos complexos metamórficos e respectivos ângulos de mergulho.

\section{AGRADECIMENTOS}

Este trabalho resultou do Trabalho de Conclusão do Curso de Graduação em Geofísica, com bolsa de Iniciação Científica PIBICCNPq. Agradecemos ao técnico Clarino do Divino Vieira pelo auxílio nos trabalhos de campo. 0 trabalho teve apoio financeiro do Projeto Temático Fapesp (processo 2000/00806-5).

\section{REFERÊNCIAS}

BLITZKOW D, GASPARINI P, SÁ NC, MANTOVANI MSM. 1979. Crustal structure of southeastern Minas Gerais, Brazil, Deduced from gravity measurements. Revista Brasileira de Geociências, 9(3): 39-43.

CARNEIRO MA. 1992. O Complexo Metamórfico Bonfim Setentrional (Quadrilátero Ferrífero, Minas Gerais): Litoestratigrafia e Evolução Geológica de um Segmento de Crosta Continental do Arqueano. São Paulo. Tese de Doutoramento, Instituto de Geociências da Universidade de São Paulo. 233 pp.

CARNEIRO MA, CARVALHO JÚNIOR IM \& TEIXEIRA W. 1998. PetroIogia, Geoquímica e Geocronologia dos diques máficos do Complexo Metamórfico Bonfim Setentrional (Quadrilátero Ferrífero) e suas implicações na evolução crustal do Cráton do São Francisco Meridional, Revista Brasileira de Geociências, 28: 29-44.

CHEMALE FJR, ROSIÈRE CA \& ENDO I. 1994. The tectonic evolution of the Quadrilátero Ferrífero, Minas Gerais, Brazil, Precambrian Research, 65: 25-54.

ENDO I \& MACHADO R. 2002. Reavaliação e novos dados geocro- nológicos (Pb/Pb e K/Ar) da Região do Quadrilátero Ferrífero e adjacências, Geologia USP Série Científica, São Paulo, 2: 23-40.

FRANÇA GS \& ASSUMPÇÃO M. 2004. Crustal structure of the Ribeira fold belt, SE Brazil, derived from receiver functions, Journal of South American Earth Sciences, 16: 743-758.

SÁ NC, USSAMI N \& MOLINA EC. 1993. Gravity Map of Brazil. Representation of Free-Air and Bouguer Anomalies, Journal of Geophysical Research - Solid Earth, 98: 2187-2197.

SÁ NC. 1994. Reduções de observações gravimétricas: teoria e prática. Apostila didática, IAG/USP, Departamento de Geofísica. 90 pp.

SANTOS MST. 2005. Potencialidades do GPS em levantamentos geofísicos terrestres, Dissertação de mestrado, Instituto de Astronomia, Geofísica e Ciências Atmosféricas/USP. 140 pp.

SCHOBBENHAUS C, CAMPOS DA, DERZE GR \& ASMUS HE. 1984. Geologia do Brasil, Texto explicativo do mapa geológico do Brasil e da área oceânica adjacente incluindo depósitos minerais, Departamento Nacional de Produção Mineral, 193-248.

TALWANI M, WORZEL JL \& LANDISMANN M. 1959. Rapid Gravity Computations for Two-dimensional Bodies with Applications to the Mendocino Submarine Fracture Zone, Journal of Geophysical Research, 64: 49-59.

TEIXEIRA W, CARNEIRO MA, NOCE CM, MACHADO N, SATO K \& TAYLOR PN. 1996. Pb, Sr and Nd isotope constraints on the Archaean evolution of gneissic-granitoid complexes in the southern São Francisco Craton, Brazil, Precambrian Research, 78: 151-164.

TEIXEIRA W, SABATÉ P, BARBOSA J, NOCE CM \& CARNEIRO MA. 2000. Archean and Paleoproterozoic tectonic evolution of the São Francisco Craton, Brazil. In: CORDANI UG, MILANI EJ, TOMAZ FILHO A \& CAMPOS DA (Ed.). Tectonic Evolution of South America. $31^{\text {st }}$ International Geological Congress, Rio de Janeiro. p. 101-137.

\section{NOTAS SOBRE OS AUTORES}

Luiz Gustavo Rodrigues Pinto. Bacharel em Geofísica pela Universidade de São Paulo, 2003, atualmente cursando o doutorado na Universidade de São Paulo. Área de atuação em métodos potenciais.

Naomi Ussami. Livre-docente do Departamento de Geofísica do IAG-USP, doutorado na Universidade de Durham, Inglaterra, 1986, pós-doutorado na Universidade de Cornell, Estados Unidos, 1995. Áreas de atuação: métodos potenciais aplicados a estudos tectônicos e modelagem de processos geológicos.

Nelsi Côgo de Sá. Livre-docente do Depto. de Geofísica do IAG-USP, doutorado na Universidade de São Paulo, 1988, pós-doutorado Universidade de News Brunswick, Canadá, 1991. Área de atuação: Geodésia Física. 